\title{
Mineralization of Farm Manures and Slurries for Successive Release of Carbon and Nitrogen in Incubated Soils Varying in Moisture Status under Controlled Laboratory Conditions
}

\author{
Mohammad Rafiqul Islam 1®D, Sultana Bilkis ${ }^{1}$, Tahsina Sharmin Hoque ${ }^{1}$, Shihab Uddin ${ }^{1}$, \\ Mohammad Jahiruddin ${ }^{1}$, Mohammad Mazibur Rahman ${ }^{1}$, Mohammad Mahmudur Rahman ${ }^{2}($ ), \\ Majid Alhomrani ${ }^{3}$, Ahmed Gaber ${ }^{4}\left(\mathbb{D}\right.$ and Mohammad Anwar Hossain ${ }^{5, *} \mathbb{C}$
}

1 Department of Soil Science, Bangladesh Agricultural University, Mymensingh 2202, Bangladesh; rafiqss69@bau.edu.bd (M.R.I.); sbilkis26@gmail.com (S.B.); tahsinass@gmail.com (T.S.H.); shihab43151@bau.edu.bd (S.U.); m_jahiruddin@bau.edu.bd (M.J.); drmazibur111@gmail.com (M.M.R.)

2 Global Centre for Environmental Remediation, College of Engineering Science and Environment, The University of Newcastle, Callaghan, NSW 2308, Australia; mahmud.rahman@newcastle.edu.au

3 Department of Clinical Laboratories Sciences, The Faculty of Applied Medical Sciences, Taif University, P.O. Box 11099, Taif 21944, Saudi Arabia; m.alhomrani@tu.edu.sa

check for

updates

Citation: Islam, M.R.; Bilkis, S.;

Hoque, T.S.; Uddin, S.;

Jahiruddin, M.; Rahman, M.M.;

Rahman, M.M.; Alhomrani, M.;

Gaber, A.; Hossain, M.A.

Mineralization of Farm Manures and

Slurries for Successive Release of

Carbon and Nitrogen in Incubated

Soils Varying in Moisture Status

under Controlled Laboratory

Conditions. Agriculture 2021, 11, 846.

https://doi.org/10.3390/

agriculture11090846

Academic Editors: Laura Zavattaro and José Alfonso Gómez

Received: 23 August 2021

Accepted: 1 September 2021

Published: 3 September 2021

Publisher's Note: MDPI stays neutral with regard to jurisdictional claims in published maps and institutional affiliations.

Copyright: (c) 2021 by the authors. Licensee MDPI, Basel, Switzerland. This article is an open access article distributed under the terms and conditions of the Creative Commons Attribution (CC BY) license (https:/ / creativecommons.org/licenses/by/ $4.0 /)$.
4 Department of Biology, College of Science, Taif University, P.O. Box 11099, Taif 21944, Saudi Arabia; a.gaber@tu.edu.sa

5 Department of Genetics and Plant Breeding, Bangladesh Agricultural University, Mymensingh 2202, Bangladesh

* Correspondence: anwargpb@bau.edu.bd
Abstract: Having up-to-date knowledge on the mineralization of organic materials and release of nutrients is of paramount significance to ensure crops' nutrient demands, increase nutrient use efficiency and ensure the right fertilizer application at the right time. This study seeks to evaluate the mineralization patterns of various manures viz. cowdung (CD), cowdung slurry (CDSL), trichocompost (TC), vermicompost (VC), poultry manure (PM), poultry manure slurry (PMSL), and mungbean residues (MR). The objective being to establish their efficiency in releasing nutrients under aerobic (field capacity) and anaerobic (waterlogging) conditions. The incubation experiment was designed using a Completely Randomized Design (CRD) that took into account three variables: Manures, soil moisture, and incubation period. The mineralization of carbon (C) and nitrogen $(\mathrm{N})$ ranged from 11.2 to $100.1 \%$ higher under aerobic conditions rather than anaerobic ones. The first-order kinetic model was used to mineralize both elements. C mineralization was 45.8 to $498.1 \%$ higher in an amount from MR under both moisture conditions. For N release, MR and PM exerted maximum amounts in anaerobic and aerobic scenarios, respectively. However, the rate of $\mathrm{C}$ and $\mathrm{N}$ mineralization was faster in TC compared to other manures in both moisture conditions. Although TC was 1.4 to $37.7 \%$ more efficient in terms of rapidity of mineralization, MR and PM performed better concerning the quantity of nutrient release and soil fertility improvement. PM had 22-24\% higher N mineralization potential than PMSL while CDSL had 46-56\% higher N mineralization potential than $\mathrm{CD}$. $\mathrm{C}$ and $\mathrm{N}$ mineralization in soil was greater under aerobic conditions compared to what occurred in the anaerobic context. Depending on mineralization potential, the proper type and amount of manure should be added to soil to increase crops' nutrient use efficiency, which in turn should lead to better crop production.

Keywords: aerobic and anaerobic conditions; carbon and nitrogen mineralization; manures; release pattern; slurries

\section{Introduction}

The decline of soil fertility is endangering crop yields in many countries of the world including Bangladesh, which relies greatly on the agriculture industry for its economy and 
exports. Nutrient mining from our soils is caused by increased cropping intensity, cultivation of contemporary varieties (high yielding varieties and hybrids) and high biomass crops, nutrient loss, and unbalanced use of chemical fertilizers, with or without mixing organic manures [1,2]. Improper application of inorganic fertilizers has resulted in a considerable diminishment of soil organic matter content, thus greatly affecting soil health [3]. Adding organic sources of plant nutrients like manures and composts should be considered as a viable sustainable approach because eco-friendly technologies can restore soil fertility, enhance crop productivity and protect the environment from man-made damage [4]. According to Escobar and Hue [5], the application of organic manures in the soil directly influences organic matter content, which improves soil's physico-chemical properties and fertility, encourages microbial activities, and amends metal toxicity by complexation. Improvement and sustenance of crop yield and soil fertility might be achievable through the adoption of efficient nutrient management where manures and fertilizers are intelligently integrated.

Through mineralization, soil organic matter releases large amounts of macronutrients [6] and this process is slow so that it favors a reduction in nutrient loss and more uptake by plants. As nutrients are slowly and steadily released from manures, they are available to plants for a long time without significant loss. The main biogeochemical activity that not only increases soil fertility but also boosts crop yield is the mineralization of $\mathrm{C}$ and $\mathrm{N}$ from manures [7].

The $\mathrm{C}$ mineralization rate can be used to assess the impact of various organic and inorganic nutrient sources on soil functions [8]. Higher $\mathrm{CO}_{2}$ emissions are caused by the mineralization of soil organic $C$ as a result of physical, chemical, and biological changes and disintegration [9] mediated by microbial activities [6]. The capacity to anticipate $\mathrm{CO}_{2}$ emissions released into the environment and nutrient availability to plants require determining $\mathrm{C}$ mineralization from organic components in soil [10].

On the other hand, $\mathrm{N}$ mineralization is an essential part of $\mathrm{N}$ cycling and transformation which is chiefly mediated through microbial activities [11,12]. Because $\mathrm{N}$ mineralization is a very complicated process that may be impacted by climatic conditions at the same time, managing $\mathrm{N}$ dynamics in organic cropping systems is a major issue $[13,14]$, soil properties $[15,16]$, and crop management $[17,18]$. As a result, a full understanding of $\mathrm{C}$ and $\mathrm{N}$ mineralization from manures in the soil is critical, as it will aid farmers in more effectively implementing an integrated nutrient management strategy. Doing so will minimize the overuse of chemical fertilizers while also protecting the environment.

The correct quantity of manures can be promptly estimated from the accurate determination of nutrient mineralization and the mineralization process and nutrient availability from various manures. This is because organic sources are essential for avoiding nutrient deficiency, maintaining proper plant nutrition, and improving successful crop production. Information obtained from research on nutrient mineralization from commonly used farm manures, composts, and slurries are crucial because based on mineralization patterns, a proper synchronization between nutrient release from organic manures and time of chemical fertilizer application can be possible. Manures and composts vary in terms of composition and potential for mineralization. The rapidity of mineralization and nutrient release capacity of organic materials largely determines their suitability as fertilizers [19]. Choosing the best manure for application at the right time and in the right amount can improve soil fertility management, ensure food security and mitigate climate-change-induced risks. Currently, information on $\mathrm{C}$ and $\mathrm{N}$ mineralization in wet and waterlogged soils treated with organic manures in Bangladesh is still sparse and inconsistent. This study was undertaken to firstly, determine the $\mathrm{C}$ and $\mathrm{N}$ mineralization kinetics of different organic manures under various moisture levels; and secondly, establish the best organic manure which will be a substitute for chemical fertilizers in terms of nutrient supply in our farming system. 


\section{Materials and Methods}

\subsection{Collection and Preparation of Soil Samples and Manures}

Soil samples were taken from the field laboratory of the Department of Soil Science at Bangladesh Agricultural University (BAU), Mymensingh, which was part of the AEZ-9 (Old Brahmaputra Floodplain). Soil samples were gathered from non-experimental fields (crops cultivated without the use of an experiment) and combined to create composite soil samples that were taken to the lab. Cowdung, poultry manure, and mungbean residues were collected from the BAU farm while trichocompost was collected from an NGO named Gono Kallyan Swabolambi Sangstha (GKSS) in Bogura district. Cowdung slurry and poultry manure slurry were collected from a biogas plant located at Boira village that is part of Mymensingh Sadar Upazila, located in the Mymensingh district. Both soil and manure samples were air-dried by spreading them on brown paper for several days and processed by grinding and sieving through a $2 \mathrm{~mm}$ sieve so that all unwanted extraneous materials were discarded. After sieving, the soil samples were put in polyethylene bags followed by incubation under aerobic conditions for 3 weeks at room temperature $\left(25^{\circ} \mathrm{C}\right)$. The physico-chemical properties of the soils are stated in Table 1 . The ground manure samples were maintained in paper bags before being placed in a desiccator for nutritional element analysis. Prior to the incubation experiment commencing, all of the samples were kept cold and dry. The total $\mathrm{N}$ and $\mathrm{C}$ concentrations were measured by the Kjeldahl digestion method [20] and weight loss in the ignition method known as Walkley and Black method [21]. Ground manure samples were digested using a di-acid combination of $\mathrm{HNO}_{3}-\mathrm{HClO}_{4}$ (3:1) as reported by Piper [22], and total $\mathrm{P}$ and $\mathrm{S}$ were measured using colorimetric and turbidimetric methods, respectively, as recommended by Yamakawa [23]. Table 2 summarizes the chemical composition of the organic manures used for the study.

Table 1. Physico-chemical characteristics of the soil samples.

\begin{tabular}{cccc}
\hline Soil Characteristics & Values & Methods & Reference \\
\hline Particle size distribution (USDA system): & & & \\
\% Sand $(0.2-0.05 \mathrm{~mm})$ & 1.4 & & \\
$\%$ Silt $(0.05-0.002 \mathrm{~mm})$ & 80 & & \\
\% Clay $(<0.002 \mathrm{~mm})$ & 18.6 & Hydrometer method & Black et al. [24] \\
Textural class & Silt loam & Gravimetric method & Walkey and Black [21] \\
Water holding capacity $(\%)$ & 51.5 & Walkley and Black method & Chapman [26] \\
Organic C $(\%)$ & 2.15 & Sodium saturation method & Jackson et al. [27] \\
Cation exchange capacity $\left(\mathrm{cmol} \mathrm{kg}{ }^{-1}\right)$ & 12.1 & Glass electrode pH meter method & Bremner and Mulvaney [28] \\
pH & 0.5 & Semi-micro Kjeldahl method & Olsen et al. [29] \\
Total N $(\%)$ & 9.119 & Olsen method & Knudsen et al. [30] \\
Available P $\left(\mathrm{mg} \mathrm{kg}^{-1}\right)$ & 0.12 & Ammonium acetate extraction method & Williams and Steinbergs [31] \\
Exchangeable K $\left(\mathrm{cmolkg}^{-1}\right)$ & 25.3 & Calcium chloride extraction method &
\end{tabular}

Table 2. Organic manures used in mineralization study with chemical composition.

\begin{tabular}{cccccccc}
\hline Manure & $\mathbf{C ~ ( \% )}$ & $\mathbf{N ~ ( \% )}$ & $\mathbf{P ~ ( \% )}$ & $\mathbf{S ~ ( \% )}$ & $\mathbf{C : N}$ & C:P & C:S \\
\hline CD & $33.14 \pm 1.91 \mathrm{~b}$ & $1.27 \pm 0.07 \mathrm{~d}$ & $0.50 \pm 0.03 \mathrm{~d}$ & $0.28 \pm 0.02 \mathrm{~d}$ & $26.2 \pm 1.51 \mathrm{~b}$ & $66.8 \pm 3.86 \mathrm{~b}$ & $118.4 \pm 6.84 \mathrm{a}$ \\
CDSL & $20.88 \pm 1.21 \mathrm{c}$ & $1.90 \pm 0.11 \mathrm{c}$ & $1.23 \pm 0.07 \mathrm{c}$ & $0.48 \pm 0.03 \mathrm{bc}$ & $11.0 \pm 0.64 \mathrm{e}$ & $17.0 \pm 0.98 \mathrm{~d}$ & $43.5 \pm 2.51 \mathrm{de}$ \\
PM & $33.54 \pm 1.94 \mathrm{~b}$ & $3.08 \pm 0.18 \mathrm{a}$ & $2.33 \pm 0.13 \mathrm{a}$ & $0.56 \pm 0.03 \mathrm{~b}$ & $10.9 \pm 0.63 \mathrm{e}$ & $14.4 \pm 0.83 \mathrm{~d}$ & $59.9 \pm 3.46 \mathrm{c}$ \\
PMSL & $22.34 \pm 1.29 \mathrm{c}$ & $2.69 \pm 0.16 \mathrm{~b}$ & $2.49 \pm 0.14 \mathrm{a}$ & $0.69 \pm 0.04 \mathrm{a}$ & $8.3 \pm 0.48 \mathrm{e}$ & $9.0 \pm 0.52 \mathrm{~d}$ & $32.4 \pm 1.87 \mathrm{e}$ \\
TC & $19.41 \pm 1.12 \mathrm{c}$ & $1.32 \pm 0.08 \mathrm{~d}$ & $1.76 \pm 0.10 \mathrm{~b}$ & $0.57 \pm 0.03 \mathrm{~b}$ & $14.7 \pm 0.85 \mathrm{~d}$ & $11.0 \pm 0.64 \mathrm{~d}$ & $34.1 \pm 1.97 \mathrm{e}$ \\
VC & $22.81 \pm 1.32 \mathrm{c}$ & $1.15 \pm 0.07 \mathrm{~d}$ & $0.52 \pm 0.03 \mathrm{~d}$ & $0.42 \pm 0.02 \mathrm{c}$ & $19.9 \pm 1.15 \mathrm{c}$ & $43.9 \pm 2.53 \mathrm{c}$ & $54.3 \pm 3.14 \mathrm{~d}$ \\
MR & $45.60 \pm 2.63 \mathrm{a}$ & $1.29 \pm 0.07 \mathrm{~d}$ & $0.45 \pm 0.03 \mathrm{~d}$ & $0.46 \pm 0.03 \mathrm{c}$ & $35.4 \pm 2.04 \mathrm{a}$ & $101.3 \pm 5.85 \mathrm{a}$ & $99.1 \pm 5.72 \mathrm{~b}$ \\
\hline
\end{tabular}

Figures having common letters do not differ significantly at the $5 \%$ level of significance. CD, CDSL, PM, PMSL, TC, VC, and MR denote cowdung, cowdung slurry, poultry manure, poultry manure slurry, trichocompost, vermicompost, and mungbean residue, respectively. Figures in the column of the table indicate mean \pm standard deviation. 


\subsection{Analysis of Soil for Both Initial and Different Incubation Periods}

The physico-chemical properties of the initial soil samples such as texture, water holding capacity, cation exchange capacity (CEC), $\mathrm{pH}$, organic $\mathrm{C}$, total $\mathrm{N}$, available phosphorus $(\mathrm{P})$, exchangeable potassium (K), and available sulfur (S) were estimated according to the standard protocols as shown in Table 1 . Nitrogen mineralization was evaluated by periodical quantification of mineral $\mathrm{N}$ in the soil-manure mixture. For measurement of $\mathrm{NO}_{3}{ }^{-}-\mathrm{N}$ and $\mathrm{NH}_{4}{ }^{+}-\mathrm{N}$, the soil was extracted using $\mathrm{CaCl}_{2}(0.01 \mathrm{M})$ and $\mathrm{KCl}(1 \mathrm{M})$ solution, respectively maintaining a 1:5 soil: extractant ratio [32,33]. Samples were agitated for half an hour on a reciprocal shaker followed by filtration. The $\mathrm{CaCl}_{2}$ extracts were analyzed by ultraviolet spectrophotometer at $210 \mathrm{~nm}$ and $275 \mathrm{~nm}$ for measuring $\mathrm{NO}_{3}{ }^{-}-\mathrm{N}$ concentration [34]. Meanwhile, $\mathrm{KCl}$ extracts were examined colorimetrically by the indophenol blue method using UV-Vis spectrophotometer at $636 \mathrm{~nm}$ for determining $\mathrm{NH}_{4}{ }^{+}-\mathrm{N}$ concentration [35].

\subsection{Experiment Set-Up}

With three replications, the experiment was set up in a Completely Randomized Design (CRD). The mineralization of organic manures and release of $C$ and $N$ was investigated in a controlled environment (aerobic and anaerobic conditions) for $0,15,30,45$, $60,75,90,150$, and 180 days. The treatments included control (without manure), and seven manures viz. CD, CDSL, PM, PMSL, TC, VC, and MR. So, there were three factors to consider in the experiment, these being organic manures, moisture conditions, and incubation periods. The fresh manures varied in moisture content but after air drying, all the manures contained approximately $2-3 \%$ moisture. Air-dried soil of $100 \mathrm{~g}$ was weighed into plastic containers and was thoroughly mixed with $1 \mathrm{~g}$ of organic manures (at the rate of $20 \mathrm{t} \mathrm{ha}^{-1}$ in the farmer's field). The modified soil's moisture content was kept at field capacity (22-25\% moisture) and saturated throughout the experiment $(1 \mathrm{~cm}$ standing water above the soil). Each set of containers was incubated at $25^{\circ} \mathrm{C}$ in the incubation room until the desired period.

\subsection{Determination of N Mineralization}

For measuring $\mathrm{N}$ mineralization, PVC pipes (inner diameter $5.5 \mathrm{~cm}$ and height $15 \mathrm{~cm}$ ) were used for dry soil (aerobic incubation) and plastic pots (inner diameter $7 \mathrm{~cm}$ and height $12 \mathrm{~cm}$ ) were utilized for wet soil (anaerobic incubation). All of the containers were kept in a dark incubation chamber at a temperature of $25 \pm 1{ }^{\circ} \mathrm{C}$ and wrapped in parafilm to prevent water loss. They were then put in an air-conditioned chamber with sufficient aeration. Soil moisture content was checked once per week. The soil moisture evaporation loss was reduced by the proper addition of deionized water to the soil to maintain the specific moisture content (field capacity and saturated condition). Taken together, 432 PVC pipes/plastic cups were filled up with aerobic and anaerobic incubations in this destructive sampling. The first sampling took place on the second day of incubation, and the results were utilized to determine the soil's initial composition. The starting weights of the soilfilled PVC tubes were also recorded. The quantity of $\mathrm{N}$ released in untreated control soil was subtracted from that in manure supplemented soil to calculate net $\mathrm{N}$-mineralization.

\subsection{Determination of C Mineralization}

The $\mathrm{CO}_{2}$ evolution method was followed to measure the rate of $\mathrm{C}$ mineralization from organic manure. For quantification of $\mathrm{CO}_{2}$ evolution, $100 \mathrm{~g}$ air-dried soil and $1 \mathrm{~g}$ manure were weighed into a series of PVC pipes and plastic cups and put into $2 \mathrm{~L}$ plastic jars. Ten $\mathrm{mL}$ of $1 \mathrm{M} \mathrm{NaOH}$ solution was put into a $50-\mathrm{mL}$ beaker and placed inside the plastic jar. The plastic containers were firmly sealed and incubated in the incubation chamber for 180 days at a temperature of $25 \pm 1{ }^{\circ} \mathrm{C}$. The quantity of $\mathrm{CO}_{2}$ entrapped with $\mathrm{NaOH}$ was measured by titration with $0.5 \mathrm{M} \mathrm{HCl}$ using $1 \mathrm{~mL}$ of saturated $\mathrm{BaCl}_{2}$. The first measurement was taken 2 days after incubation (DAI), the following measurements were taken at $4 \mathrm{DAI}$, then at 7-day intervals until 56 days thereafter at 15-day intervals until the end of the investigation. The unused alkali was titrated back with standard $0.5 \mathrm{M} \mathrm{HCl}$ after precipitating carbonate 
with $\mathrm{BaCl}_{2}$ [36]. During titration, 2-3 drops of indicator (phenolphthalein) were included in the $\mathrm{NaOH}$ solution followed by titration against $0.5 \mathrm{M} \mathrm{HCl}$. The endpoint of the reaction was identified by the solution changing color from pink to colorless.

The mass of $\mathrm{CO}_{2}$ generated was calculated using the following formula [37]:

$$
\mathrm{CO}_{2}-\mathrm{C}(\mathrm{mg})=\frac{\mathrm{HCl}_{\mathrm{b}}-\mathrm{HCl}_{\mathrm{s}}}{1000 \mathrm{ml} \mathrm{L}^{-1}} \times \mathrm{HCl} \text { molarity }\left(\mathrm{mol} \mathrm{L}^{-1}\right) \times 12 \mathrm{~g} \mathrm{C} \mathrm{mol}^{-1} \times 1000 \mathrm{mg} \mathrm{g}^{-1}
$$

Here, $\mathrm{HCl}_{\mathrm{b}}=\mathrm{mL} \mathrm{HCl}$ used in titration for blank; $\mathrm{HCl}_{\mathrm{s}}=\mathrm{mL} \mathrm{HCl}$ used in titration for sample; $\mathrm{CO}_{2}-\mathrm{C}=$ mass of $\mathrm{CO}_{2}$-carbon generated $(\mathrm{mg})$;

Which simplifies to: $\mathrm{CO}_{2}-\mathrm{C}(\mathrm{mg})=\left(\mathrm{HCl}_{\mathrm{b}}-\mathrm{HCl}_{\mathrm{s}}\right) \times 12$

\subsection{Fitting of Mineralization Data to the First Order Kinetic Model}

The first-order kinetic model fitted well for calculating both $\mathrm{C}$ and $\mathrm{N}$ mineralization. According to this model, as provided by Stanford and Smith [38], $\mathrm{C}_{\mathrm{t}}=\mathrm{C}_{0}\left(1-\mathrm{e}^{-\mathrm{kt}}\right)$, where $\mathrm{C}_{\mathrm{t}}$ is the carbon mineralized from the soil once the control is subtracted (as $\left.\mathrm{CO}_{2}-\mathrm{C}\right)$ in a given time $t, C_{0}$ is the potentially mineralizable pool of organic $C$, and $k$ is the mineralization constant rate. According to Stanford and Smith [38], N mineralization can be estimated by fitting simple kinetic models to temporal data of soil N. For long-term incubations at high temperature, a first-order exponential model is used to predict net $\mathrm{N}$ mineralization. The equation for $\mathrm{N}$ was $\mathrm{N}_{t}=\mathrm{N}_{0}\left(1-\mathrm{e}^{-\mathrm{kt}}\right)$, where $\mathrm{N}_{\mathrm{t}}$ is the net nitrogen mineralized at time $\mathrm{t}$, $\mathrm{N}_{0}$ is the potentially mineralizable nitrogen and $\mathrm{k}$ is the rate constant.

\subsection{Statistical Analysis}

The experimental data were subjected to analysis of variance (ANOVA) technique using Statistix 10 software package by Repeated Measures Design. The Sigma Plot 13 software served to complete the fits and kinetic parameters. Post-hoc tests were conducted to separate differences among treatments at the same time interval, rate constant, and potentially mineralizable nutrients using the Tukey-Kramer multiple comparisons. All statistical analyses were considered significant at $p<0.05$ unless otherwise stated.

\section{Results}

\subsection{Carbon Mineralization and Release Pattern from OM Amended Soils}

\subsubsection{Trend of Net Carbon Mineralization Rate}

Net carbon mineralization rate was several times higher in aerobic than anaerobic conditions (Figure $1 \mathrm{a}, \mathrm{b}$ ). In the former, $\mathrm{C}$ mineralization started much earlier compared to the latter and reached its peak within 3 to 6 days for all the manures. After attaining the peak, it fell drastically and thereafter mineralization rate decreased gradually to reach a steady-state point after 33 days. After 180 days of incubation, net $C$ mineralization reached approximately zero. In anaerobic conditions, net $C$ mineralization started within 3 days and increased progressively to attain the peak within 6 to 12 days for all treatments. After attaining the peak, it declined gradually with the incubation time and disappeared at day 120. The maximum evolution of $\mathrm{CO}_{2}$ at a rate of 38.5 and $15.7 \mathrm{mg} \mathrm{g}^{-1}$ manure was found from MR in aerobic and anaerobic situations, respectively, across the incubation time.

\subsubsection{Cumulative Net $C$ Mineralization}

The patterns of cumulative $C$ mineralization of different manures in the soils across the moisture regimes and incubation times are shown in Figure 1c,d. The lowest cumulative net $C$ mineralization was detected in CDSL under both aerobic and anaerobic conditions. As well, cumulative net $C$ mineralization from CDSL and PMSL was lower compared to their manure state (i.e., $\mathrm{CD}$ and PM). After incubation lasting 180 days the highest cumulative $\mathrm{C}$ mineralization trend under aerobic conditions followed the order: $\mathrm{MR}$ (216.9 $\mathrm{mg} \mathrm{g}^{-1}$ manure $)>\mathrm{CD}\left(146.7 \mathrm{mg} \mathrm{g}^{-1}\right.$ manure $)>\mathrm{PM}\left(102.9 \mathrm{mg} \mathrm{g}^{-1}\right.$ manure $)>\mathrm{VC}$ (55.4 $\mathrm{mg} \mathrm{g}^{-1}$ manure) $>$ PMSL (55.2 $\mathrm{mg} \mathrm{g}^{-1}$ manure) $>\mathrm{TC}\left(46.9 \mathrm{mg} \mathrm{g}^{-1}\right.$ manure $)>$ 
CDSL (34.5 $\mathrm{mg} \mathrm{g}^{-1}$ manure) (Figure 2c). The trend under anaerobic conditions was MR (114.4 $\mathrm{mg} \mathrm{g}^{-1}$ manure) $>$ PM $\left(46.1 \mathrm{mg} \mathrm{g}^{-1}\right.$ manure $)>\mathrm{CD}\left(41.3 \mathrm{mg} \mathrm{g}^{-1}\right.$ manure $)>\mathrm{VC}$ (39.1 $\mathrm{mg} \mathrm{g}^{-1}$ manure) $>$ PMSL (31.5 $\mathrm{mg} \mathrm{g}^{-1}$ manure) $>$ TC $\left(27.1 \mathrm{mg} \mathrm{g}^{-1}\right.$ manure $)>$ CDSL (24.99 $\mathrm{mg} \mathrm{g}^{-1}$ manure) (Figure $2 \mathrm{~d}$ ). Different $C$ sources (i.e., manures) significantly affected cumulative net release of $\mathrm{C}$ as $\mathrm{CO}_{2}$ during the incubation period.

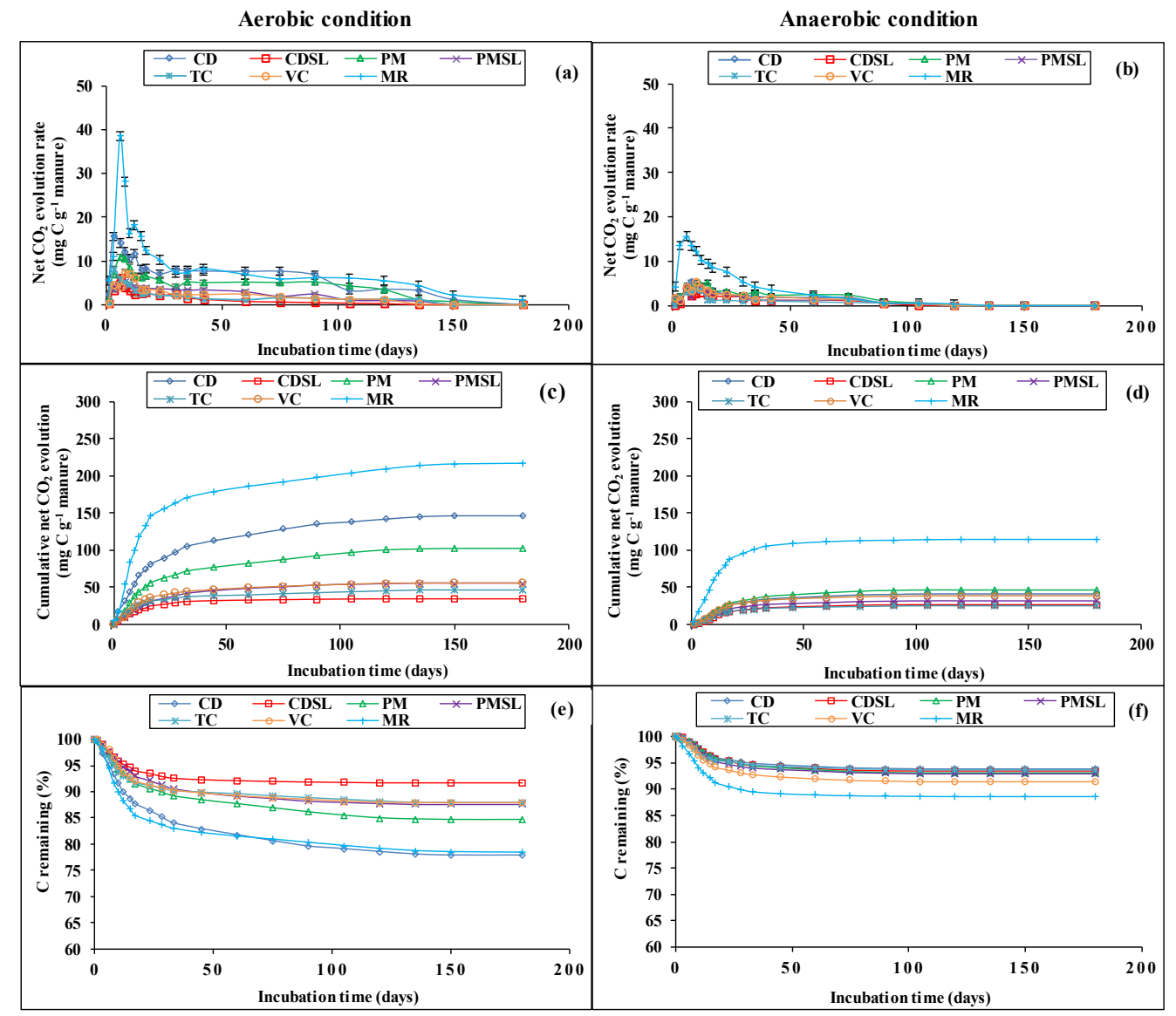

Figure 1. Trends of $\mathrm{CO}_{2}$ evolution rate $\left({\mathrm{mg} \mathrm{C} 100 \mathrm{~g}^{-1} \text { soil day }}^{-1}\right)$ under aerobic (a) and anaerobic (b) conditions, cumulative $\mathrm{CO}_{2}$ evolution rate (mg $100 \mathrm{~g}^{-1}$ soil) under aerobic (c) and anaerobic (d) conditions, and remaining rate of $\mathrm{C}$ in manure-treated soils under aerobic (e) and anaerobic (f) conditions. Values represent the means \pm standard deviation of three independent experiments.

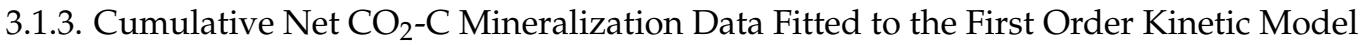

The values of parameters and coefficients of determination for $\mathrm{C}$ mineralization kinetics are shown in Table 3. The data for $C$ mineralization fitted very well with the first-order kinetic model i.e., $C_{t}=C_{0}\left(1-\mathrm{e}^{-k t}\right)$, the $\mathrm{R}^{2}$ value being found 0.977 to 0.994 in aerobic conditions and 0.369 to 0.879 in anaerobic conditions. Referring to the manure types, the $\mathrm{C}_{0}$ value, i.e., mineralization potential was greater every time under aerobic conditions in comparison with respective anaerobic conditions. The highest mineralization potential $\left(C_{0}\right)$ of 204.32 and $159.17 \mathrm{mg} \mathrm{g}^{-1}$ manure was recorded for MR under aerobic and anaerobic conditions, respectively. PMSL had lower mineralization potential than its manure state (i.e., PM) in both aerobic and anaerobic conditions while CDSL had higher mineralization potential compared to $\mathrm{CD}$. Overall, the results indicate that MR was more responsive to $\mathrm{C}$ mineralization followed by $\mathrm{CD}$ and $\mathrm{PM}$ considering mineralization potential values. $\mathrm{C}$ mineralization rate was more or less similar in both moisture conditions. The greatest mineralization rate constant was found in TC under aerobic conditions, followed by CDSL, MR, VC, CD, PMSL, and PM, respectively. Concerning the anaerobic conditions, mineralization rate constant can be ranked as TC $>$ MR $>$ CDSL $>$ VC $>$ PMSL $>$ CD $>$ PM. 
These results strongly suggest that TC undergo faster mineralization, i.e., decomposition and PM decomposed the least. CDSL undergoes quick mineralization under aerobic conditions compared to anaerobic conditions.

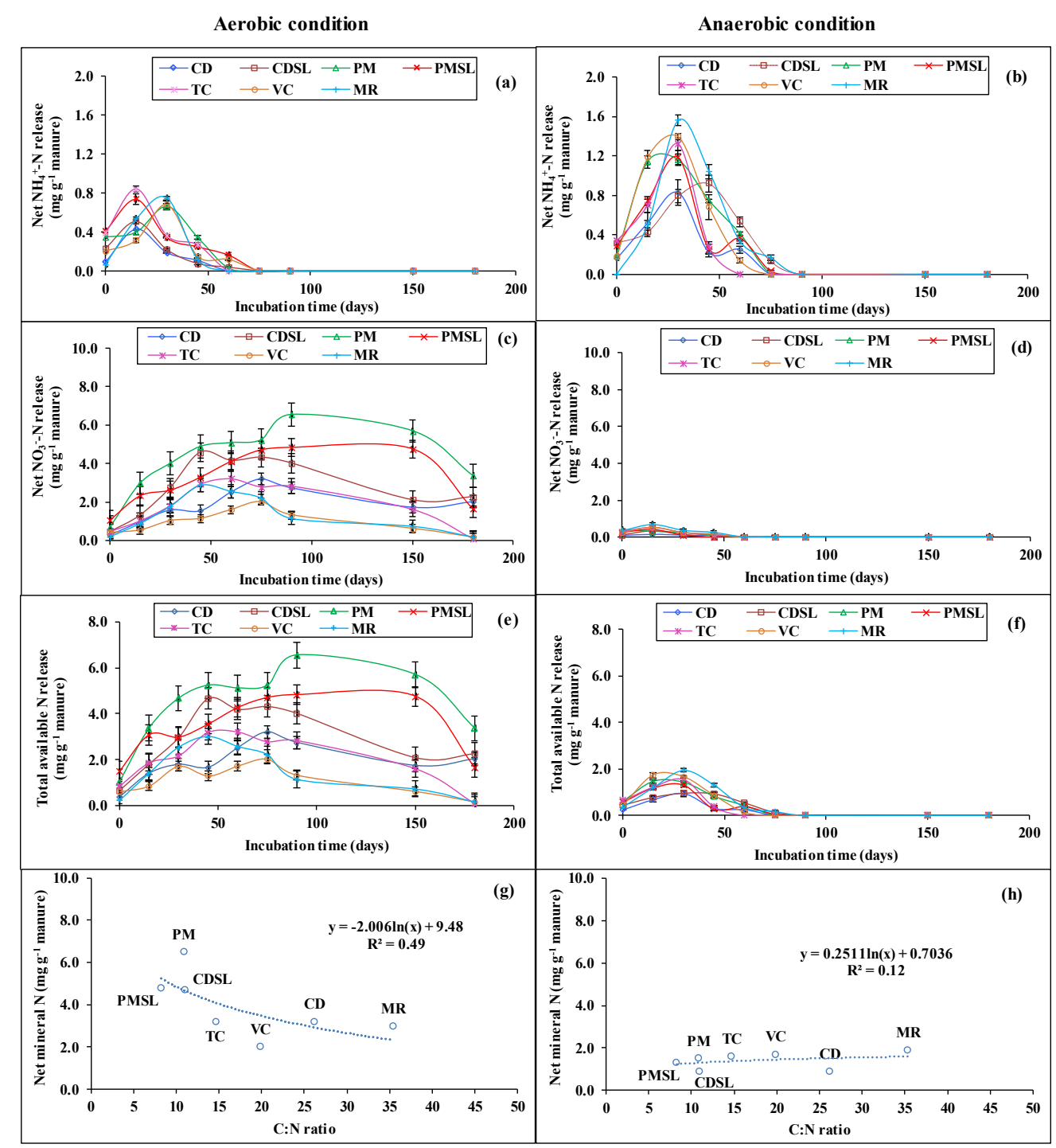

Figure 2. Net $\mathrm{NH}_{4}{ }^{+}-\mathrm{N}$ mineralization from various manures in aerobic (a) and anaerobic (b) situations, net $\mathrm{NO}_{3}{ }^{-}-\mathrm{N}$ mineralization from various manures in aerobic (c) and anaerobic (d) situations, and net available $\mathrm{N}\left(\mathrm{NH}_{4}{ }^{+}+\mathrm{NO}_{3}{ }^{-}\right)$mineralization from various manures in aerobic (e) and anaerobic (f) situations, which is estimated as the deviation in quantity between manure and control treatment. Relationship between net $\mathrm{N}$ accumulation, calculated on 180 days after incubation and initial manure $\mathrm{C} / \mathrm{N}$ ratio in aerobic $(\mathbf{g})$ and anaerobic situations $(\mathbf{h})$. Values represent the mean \pm standard deviation of three independent experiments.

The mineralization rate constant of the first-order kinetic model was much higher under the aerobic situation in comparison to that in the anaerobic situation (Table 3). It indicates that $\mathrm{C}$ mineralization took place very slowly under anaerobic conditions and it took longer to decompose manures. For the manures, the $\mathrm{k}$ value of the first-order kinetic model was found to be higher in cowdung and poultry manure slurry compared to their original state. 


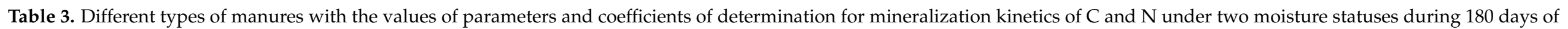
incubation.

\begin{tabular}{|c|c|c|c|c|c|c|c|c|c|c|c|c|c|c|c|c|}
\hline \multirow{3}{*}{ Manures } & \multicolumn{8}{|c|}{ Carbon Mineralization Kinetics } & \multicolumn{8}{|c|}{ Nitrogen Mineralization Kinetics } \\
\hline & \multicolumn{4}{|c|}{ Aerobic Incubation } & \multicolumn{4}{|c|}{ Anaerobic Incubation } & \multicolumn{4}{|c|}{ Aerobic Incubation } & \multicolumn{4}{|c|}{ Anaerobic Incubation } \\
\hline & $\mathrm{C}_{0}$ & $\mathbf{k}$ & radj* & $F$ & $\mathrm{C}_{0}$ & $\mathbf{k}$ & r adj* & $F$ & $\mathrm{~N}_{0}$ & $\mathbf{k}$ & $\mathbf{r}$ adj * & F & $\mathrm{N}_{0}$ & $\mathbf{k}$ & r adj * & F \\
\hline $\mathrm{CD}$ & 140.16 & 0.045 & 0.986 & $\begin{array}{c}1322.41 \\
(p<0.0001)\end{array}$ & 90.57 & 0.047 & 0.369 & $\begin{array}{c}23.78 \\
(p<0.0001)\end{array}$ & 4.93 & 0.003 & 0.976 & $\begin{array}{c}203.3 \\
(p<0.0001)\end{array}$ & 2.48 & 0.042 & 0.965 & $\begin{array}{c}29.7 \\
(p<0.0001)\end{array}$ \\
\hline CDSL & 34.16 & 0.068 & 0.994 & $\begin{array}{c}3131.95 \\
(p<0.0001)\end{array}$ & 30.71 & 0.059 & 0.879 & $\begin{array}{c}285.0 \\
(p<0.0001)\end{array}$ & 7.20 & 0.003 & 0.979 & $\begin{array}{c}382.8 \\
(p<0.0001)\end{array}$ & 3.87 & 0.032 & 0.959 & $\begin{array}{c}23.44 \\
(p<0.0001)\end{array}$ \\
\hline PM & 98.26 & 0.043 & 0.981 & $\begin{array}{c}992.0 \\
(p<0.0001)\end{array}$ & 72.19 & 0.044 & 0.593 & $\begin{array}{c}57.78 \\
(p<0.0001)\end{array}$ & 9.68 & 0.004 & 0.934 & $\begin{array}{c}114.5 \\
(p<0.0001)\end{array}$ & 4.84 & 0.042 & 0.963 & $\begin{array}{c}30.31 \\
(p<0.0001)\end{array}$ \\
\hline PMSL & 54.154 & 0.044 & 0.993 & $\begin{array}{c}2596.1 \\
(p<0.0001)\end{array}$ & 42.81 & 0.047 & 0.747 & $\begin{array}{c}115.9 \\
(p<0.0001)\end{array}$ & 7.31 & 0.004 & 0.700 & $\begin{array}{c}19.68 \\
(p<0.0030)\end{array}$ & 3.77 & 0.047 & 0.947 & $\begin{array}{c}27.87 \\
(p<0.0001)\end{array}$ \\
\hline $\mathrm{TC}$ & 44.28 & 0.069 & 0.978 & $\begin{array}{c}843.3 \\
(p<0.0001)\end{array}$ & 34.52 & 0.067 & 0.616 & $\begin{array}{c}63.48 \\
(p<0.0001)\end{array}$ & 4.48 & 0.004 & 0.876 & $\begin{array}{c}57.95 \\
(p<0.0001)\end{array}$ & 3.88 & 0.057 & 0.937 & $\begin{array}{c}27.60 \\
(p<0.0001)\end{array}$ \\
\hline $\mathrm{VC}$ & 53.92 & 0.055 & 0.978 & $\begin{array}{c}861.4 \\
(p<0.0001)\end{array}$ & 46.44 & 0.056 & 0.856 & $\begin{array}{c}233.2 \\
(p<0.0001)\end{array}$ & 2.57 & 0.003 & 0.864 & $\begin{array}{c}51.85 \\
(p<0.0002)\end{array}$ & 4.92 & 0.048 & 0.975 & $\begin{array}{c}37.49 \\
(p<0.0001)\end{array}$ \\
\hline MR & 204.32 & 0.063 & 0.977 & $\begin{array}{c}797.0 \\
(p<0.0001)\end{array}$ & 159.17 & 0.067 & 0.652 & $\begin{array}{c}74.0 \\
(p<0.0001)\end{array}$ & 4.75 & 0.003 & 0.991 & $\begin{array}{c}856.1 \\
(p<0.0001)\end{array}$ & 5.54 & 0.034 & 0.956 & $\begin{array}{c}22.55 \\
(p<0.0001)\end{array}$ \\
\hline
\end{tabular}

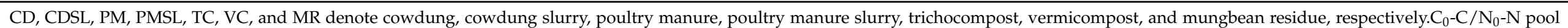

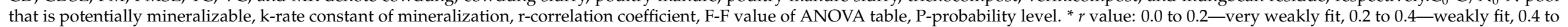
0.7 - moderately fit, 0.7 to 0.9 -strongly fit, 0.9 to 1.0 - very strongly fit. 


\subsubsection{Carbon Remaining}

Carbon remaining (\%) as a function of $\mathrm{CO}_{2}$ evolution from soil amended with different manures under dry and wet conditions is displayed in Figure 1e,f. Among organic manures, $\mathrm{C}$ remaining rate was the lowest in mungbean residue across the moisture regimes and incubation times. The lowest decomposition was recorded by cowdung slurry and cowdung, respectively, under aerobic and anaerobic conditions which showed the highest remaining $(\%)$. Indicated here was a more stable state to carbon release. Next to cowdung slurry, the trichocompost recorded the second-highest $C$ remaining rate under aerobic conditions.

\subsection{Nitrogen Mineralization}

\subsection{1. $\mathrm{NH}_{4}{ }^{+}-\mathrm{N}$ Release Pattern}

Figure 2a,b shows the pattern of $\mathrm{NH}_{4}{ }^{+}-\mathrm{N}$ mineralization from various types of manures in aerobic and anaerobic situations in different treatments over time. TC and MR showed the maximum evolution of $\mathrm{NH}_{4}{ }^{+}-\mathrm{N}$ at a rate of 0.84 and $1.56 \mathrm{mg} \mathrm{g}^{-1}$ manure in aerobic and anaerobic situations, respectively, across the incubation time. It seemed that manure amended soil in anaerobic conditions exhibited greater $\mathrm{NH}_{4}{ }^{+}-\mathrm{N}$ mineralization compared to aerobic conditions. Nevertheless, $\mathrm{NH}_{4}{ }^{+}-\mathrm{N}$ mineralization attained the highest level in aerobic conditions at 15 days of incubation with the exceptions being PM, VC, and MR where the peak was reached within 30 days. After that, the mineralization decreased gently and dropped to near zero after 75 days (Figure 2a,b). In continuous standing water conditions, the situation was comparable to aerobic conditions in that $\mathrm{NH}_{4}{ }^{+}-\mathrm{N}$ mineralization peaked in 30 days and subsequently plummeted to near nil between days 60 and 150.

\subsection{2. $\mathrm{NO}_{3}{ }^{-}-\mathrm{N}$ Release Pattern}

Concerning the kinds of manure, moistures, and incubation period, the $\mathrm{NO}_{3}{ }^{-} \mathrm{N}$ released under aerobic conditions was several times higher compared to the anaerobic scenario (Figure 2c,d). The $\mathrm{NO}_{3}{ }^{-}$-with the passage of time, $\mathrm{N}$ mineralization increased in aerobic conditions, peaked between 45-150 days, and then leveled out after 180 days. In 180 days of incubation, the concentration of $\mathrm{NO}_{3}{ }^{-}-\mathrm{N}$ was $2.0-6.5 \mathrm{mg} \mathrm{g}^{-1}$ manure in the aerobic context. The quantity of $\mathrm{NO}_{3}{ }^{-}-\mathrm{N}$ from PM and PMSL increased with the longer incubation period which strongly affected mineralization. Differing from the pattern of release in aerobic conditions, the $\mathrm{NO}_{3}{ }^{-}-\mathrm{N}$ mineralization from various manures was minute under anaerobic conditions and the peak value was reached within 45-90 days. The concentration of $\mathrm{NO}_{3}{ }^{-}-\mathrm{N}$ almost disappeared from the soil after 30 days of incubation under anaerobic conditions (Figure 2d). The results showed that CD, PM, CDSL, and PMSL had the potentials to provide prolonged $\mathrm{NO}_{3}{ }^{-}-\mathrm{N}$ supply in soil under aerobic conditions.

\subsubsection{Total Available $\mathrm{N}\left(\mathrm{NH}_{4}{ }^{+}+\mathrm{NO}_{3}{ }^{-}\right)$Mineralization}

The total $\mathrm{N}$ mineralization was several times greater in a moist situation (aerobic) than in a waterlogged situation (anaerobic). Under aerobic conditions, total $\mathrm{N}$ mineralization was first very low, but then increased until 30-90 days, after which it began to drop as time passed (Figure 2e). The magnitude of $\mathrm{N}$ mineralization from VC was low compared to that from other manures. On the other hand, poultry manure followed by its slurry performed the best in releasing the total available N. The highest mineralization of N by PM and PMSL was recorded at the 90th and 150th day of incubation. TC, CDSL, and MR reached their peak on the 45th day. CD and VC mineralization reached a peak on the 75th day. Under anaerobic conditions, the $\mathrm{N}$ mineralization from different types of manures was the highest on the 30th day, while thereafter it decreased so gradually that $\mathrm{NH}_{4}{ }^{+}-\mathrm{N}+\mathrm{NO}_{3}{ }^{-}-\mathrm{N}$ were very negligible in the soil (Figure $2 \mathrm{f}$ ).

\subsubsection{Relationship between Net $\mathrm{N}$ Accumulation and Initial Manure $\mathrm{C} / \mathrm{N}$ Ratio}

After 180 days of incubation, an inverse and exponential connection were established between the original manure $\mathrm{C} / \mathrm{N}$ ratio and net $\mathrm{N}$ buildup (Figure $2 \mathrm{~g}, \mathrm{~h}$ ). Net $\mathrm{N}$ accumula- 
tion was estimated as the deviation from $\mathrm{KCl}$ extractable $\mathrm{N}$ content of manure amended and unamended soils. Net available $\mathrm{N}$ accumulation decreased exponentially with the $\mathrm{C} / \mathrm{N}$ ratio recorded after 180 days of incubation under aerobic conditions. This relationship indicates that where the $\mathrm{C} / \mathrm{N}$ ratio is higher, $\mathrm{N}$ availability is lower in soil and vice-versa. Consequently, lower $\mathrm{C} / \mathrm{N}$ ratio containing manures like PM, PMSL, and CDSL had higher $\mathrm{N}$ availability under aerobic conditions whereas $\mathrm{MR}$ with the highest $\mathrm{C} / \mathrm{N}$ ratio had the lowest net available $\mathrm{N}$. In contrast, net available $\mathrm{N}$ accumulation had a positive exponential relationship with the $\mathrm{C} / \mathrm{N}$ ratio under anaerobic conditions, thus indicating that the higher $\mathrm{C} / \mathrm{N}$ ratio then the more $\mathrm{N}$ is available under anaerobic conditions. MR having the maximum $\mathrm{C} / \mathrm{N}$ ratio had the highest net available $\mathrm{N}$ under anaerobic conditions.

\subsubsection{Mineralization Kinetic Models and Mineralization Rates of $\mathrm{N}$}

Mineralization of $\mathrm{N}$ from different types of manure was significantly $(p<0.01)$ affected by manure type and source (Table 3). The net cumulative $\mathrm{N}$ mineralization data for all types of manure under aerobic conditions fitted properly to the first-order exponential kinetic model. Nitrogen mineralization potential $\left(\mathrm{N}_{0}\right)$ was the highest in poultry manure followed by poultry manure slurry (Table 3 ). Compared to $C$ mineralization, reverse results were found in the case of rate constant $\left(\mathrm{k}_{1}\right)$ values for $\mathrm{N}$ mineralization, where the $\mathrm{k}_{1}$ values were lower in CDSL, CD, and VC. These results indicate that the slurries had a very slow rate of $\mathrm{N}$ mineralization, yet they had the potential to liberate higher amounts of $\mathrm{N}$. In contrast, the $\mathrm{N}$ mineralization rate constant was significantly higher in anaerobic conditions than in aerobic conditions. Under aerobic conditions, TC undergoes faster mineralization, followed by PM and its slurry. Likewise, faster mineralization was also observed in TC under anaerobic conditions which were followed by VC, PMSL, CD, PM, MR, and CDSL, respectively. Demonstrated by these results is that TC mineralized quickly both under aerobic and anaerobic conditions whereas CDSL mineralized slowly. The $\mathrm{R}^{2}$ values ranged from 0.700 (in PMSL) to 0.991 (in MR) under different manure treatments and the rise in $\mathrm{R}^{2}$ values suggests a preferable and significant fit of the model in MR amended soils.

\subsubsection{Net N Release}

Net available $\mathrm{N}$ release in soil was several-fold higher in aerobic conditions compared to anaerobic ones (Table 4). Due to the application of PM, PMSL and CDSL, in moist soil (aerobic conditions), available $\mathrm{N}$-release was $6.5 \mathrm{mg} \mathrm{g}^{-1}$ manure $(28.1 \%$ of added $\mathrm{N}$ ), $4.8 \mathrm{mg} \mathrm{g}^{-1}$ manure $\left(22.2 \%\right.$ of added $\mathrm{N}$ ), and $4.7 \mathrm{mg} \mathrm{g}^{-1}$ manure $(24.5 \%$ of added $\mathrm{N}$ ), respectively. Meanwhile, in anaerobic conditions, they were $1.5 \mathrm{mg} \mathrm{g}^{-1}$ manure $(6.2 \%$ of added $\mathrm{N})$, $1.3 \mathrm{mg} \mathrm{g}^{-1}$ manure ( $6 \%$ of added $\left.\mathrm{N}\right)$, and $0.9 \mathrm{mg} \mathrm{g}^{-1}$ manure ( $\%$ of added $\left.\mathrm{N}\right)$, respectively.

Table 4. Amount of $\mathrm{N}$ added and net available $\mathrm{N}$ release from various types of manures added at $20 \mathrm{tha}^{-1} \mathrm{during}$ incubation time in aerobic and anaerobic situations.

\begin{tabular}{|c|c|c|c|c|c|}
\hline \multirow[t]{2}{*}{ Organic Manure } & \multirow{2}{*}{$\begin{array}{c}\text { N Added } \\
\text { (mgg } \\
-1 \text { Manure) }\end{array}$} & \multicolumn{2}{|c|}{$\begin{array}{l}\text { Maximum N Release in } 180 \text { Days } \\
\text { (mgg }{ }^{-1} \text { Manure) }\end{array}$} & \multicolumn{2}{|c|}{$\%$ N Release } \\
\hline & & Aerobic & Anaerobic & Aerobic & Anaerobic \\
\hline $\mathrm{CD}$ & 12.7 & $3.2 \pm 0.2 c$ & $0.9 \pm 0.6 \mathrm{~g}$ & $25.5 \pm 1.5 \mathrm{ab}$ & $7.5 \pm 0.4 \mathrm{f}$ \\
\hline CDSL & 19.0 & $4.7 \pm 0.3 \mathrm{~b}$ & $0.9 \pm 0.6 \mathrm{~g}$ & $24.5 \pm 1.4 \mathrm{~b}$ & $5.0 \pm 0.3 \mathrm{f}$ \\
\hline PM & 23.3 & $6.5 \pm 0.4 \mathrm{a}$ & $1.5 \pm 0.8 \mathrm{f}$ & $28.1 \pm 1.6 \mathrm{a}$ & $6.2 \pm 0.4 \mathrm{f}$ \\
\hline PMSL & 21.8 & $4.8 \pm 0.3 \mathrm{~b}$ & $1.3 \pm 0.8 \mathrm{f}$ & $22.2 \pm 1.3 c$ & $6.0 \pm 0.4 \mathrm{f}$ \\
\hline $\mathrm{TC}$ & 13.2 & $3.2 \pm 0.2 c$ & $1.6 \pm 0.9 \mathrm{e}$ & $24.5 \pm 1.4 \mathrm{~b}$ & $11.8 \pm 0.7 \mathrm{e}$ \\
\hline $\mathrm{VC}$ & 11.5 & $2.0 \pm 0.1 \mathrm{~d}$ & $1.7 \pm 1.0 \mathrm{de}$ & $17.7 \pm 1.0 \mathrm{~d}$ & $15.1 \pm 0.9 \mathrm{~d}$ \\
\hline MR & 12.9 & $3.0 \pm 0.2 \mathrm{c}$ & $1.9 \pm 1.1 \mathrm{de}$ & $23.4 \pm 1.4 \mathrm{bc}$ & $15.1 \pm 0.9 \mathrm{~d}$ \\
\hline
\end{tabular}

Figures having common letters do not differ significantly at the $5 \%$ level of significance. Comparisons were made between columns $3 \& 4$ and columns 5\&6. CD, CDSL, PM, PMSL, TC, VC, and MR denote cowdung, cowdung slurry, poultry manure, poultry manure slurry, trichocompost, vermicompost, and mungbean residue, respectively. Figures in the column (except the second column) of the table indicate mean \pm standard deviation. 


\section{Discussion}

In Bangladesh, the country's warm subtropical humid climate and repeated tillage operations favor the mineralization of organic materials in the soil. As the effect of drivers influencing mineralization of nutrients in manures such as moisture, characteristics of soil and manures, microbial activity, etc., cannot be accurately estimated, an approximate determination of nutrient mineralization after manure application is feasible. $\mathrm{C}$ mineralization was shown to be highly influenced by the amount and kinds of organic material added to the soil, as well as the complex interplay between soil physical, chemical, and biological processes, as well as environmental conditions such as wetness in this study (Figure 1a,b). These findings are consistent with what other analyses have reported [6,39-41], and they discovered an increase in $\mathrm{CO}_{2}$ evolution in the first few weeks of incubation, followed by a steady reduction. For a certain time onwards, organic materials had a level of stability that modified soil microbial activity resulting in reduced $\mathrm{CO}_{2}$ evolution. Reduced microbial activity characterized by a drop in $\mathrm{CO}_{2}$ might be due to: firstly, the decreased amount of easily bio-degradable organic matter; and secondly, a moderate stable microbial activity afterward indicating that the decomposition did reach the advanced stage.

Carbon dioxide is liberated in soil from microbial respiration, where micro-flora takes part in the decomposition of organic matter and the evolution of $\mathrm{CO}_{2}$ in dry and wet environments [42]. The aerobic and anaerobic conditions of soil generate $\mathrm{CO}_{2}$ and $\mathrm{CH}_{4}$, respectively, based on the accumulation of SOC. Application of various manures and organic wastes for plant nutrition will build up huge amounts of organic $\mathrm{C}$ which in turn will greatly influence $\mathrm{CO}_{2}$ emissions. Aerobic microorganisms die or become dormant under anaerobic conditions due to a lack of oxygen, which limits microbial activity on organic materials, resulting in falling $\mathrm{CO}_{2}$ emissions and the conversion of available $\mathrm{CO}_{2}$ to $\mathrm{CH}_{4}$ [43]. Initially, the rate of $\mathrm{C}$ mineralization was much higher under aerobic conditions in comparison to that under anaerobic conditions. With the rise of moisture content, $\mathrm{C}$ mineralization increased, attained the peak, and afterward declined (Figure 1a,b). Other studies [44-47] noted that $C$ mineralization displayed a parabolic response as moisture content increased, which is consistent with our findings. Low $\mathrm{C}$ mineralization under low moisture content was attributed by Taggart et al. [48] to insufficient water for microbial breakdown and limited diffusion of soluble substrate reserve. Higher $\mathrm{C}$ mineralization occurred at low moisture levels due to greater water availability for microorganisms in soil pore spaces, and as moisture levels grew, mineralization decreased due to a lack of $\mathrm{O}_{2}$ supply in the pores for microbes $[49,50]$.

Cumulative $\mathrm{C}$ mineralization of different types of manures varied due to differences in their chemical and biochemical compositions (Figure 1c,d). The overall results indicate that MR was more responsive to $C$ mineralization followed by $C D$ and PM considering mineralization potential values. Murthyet al. [39] reported that at a given rate of $C$ applied through different manures, the cumulative $C$ mineralization at various time intervals varied for different levels of $C$. Between cattle and poultry sources, cumulative $C$ mineralization was lower in slurry compared to their original state as observed in our study. The reason can be attributed to the slurry production after extraction of biogas (chiefly $\mathrm{CH}_{4}$ ) resulting in a comparatively stable state for $\mathrm{C}$ mineralization. Carbon mineralization was notably greater in the case of CD compared to PM under aerobic conditions.

Consistent with our findings, Naheret al. [51] stated that the cumulative $\mathrm{CO}_{2}$ flux was lower in the PM than in the CD treatments because PM decayed more slowly than CD. Carbon remaining rate (\%) was higher in anaerobic conditions than in aerobic conditions depending on the types of manures and time of incubation (Figure 1e,f). Our results show that the anaerobically composted slurry source is more stable to $C$ decomposition compared to the manure source. Higher $C$ remaining rate indicates a higher accumulation of $C$ in soil that was greater in anaerobic conditions compared to aerobic conditions. Murthy et al. [39] studied the $\mathrm{C}$ mineralization of four organic manures and compost in Mandya soil and observed that 14.3 to $26.7 \%$ of added $\mathrm{C}$ was mineralized as $\mathrm{CO}_{2}$ during 90 days of the incubation period. This discovery supports our $\mathrm{C}$ mineralization results of 9.1 to $21.6 \%$. 
Application of bioslurry (CDSL or PMSL) would help build up organic matter in the soil by minimizing carbon losses as $\mathrm{CO}_{2}$.

Mineralization and release of $\mathrm{N}$ from organic manure were significantly influenced by manure types, soil moistures status, and incubation period and was calculated from total $\mathrm{N}$ on the organic matter treatment minus control (Table 4). Alterations in mineralization of $\mathrm{N}$ are straightforwardly linked to microbial actions and biomass stores that are influenced by abiotic factors. Moisture condition and incubation exerted a remarkable influence on $\mathrm{N}$ mineralization from manures. Ammonification is the first step of mineralization of soil organic $\mathrm{N}$. The $\mathrm{NH}_{4}{ }^{+}-\mathrm{N}$ mineralization was the most influential form of $\mathrm{N}$ in the anaerobic condition of soil during the incubation experiment, and subsequently indicated the rapid rates of ammonification (Figure $2 a, b$ ). This outcome was highly presumed as $\mathrm{N}$ mineralization terminates at ammonification because of the shortage of $\mathrm{O}_{2}$ to make nitrification possible. Walpola and Arunakumara [52] investigated the influence of soil salinity on the $\mathrm{N}$ mineralization in animal manure amended soils and found that $\mathrm{NH}_{4}{ }^{+}-\mathrm{N}$ release peaked on the 15th day. It then gradually declined in each treatment in non-saline soil which supports our $\mathrm{NH}_{4}{ }^{+}-\mathrm{N}$ peak result. The main type of inorganic $\mathrm{N}$ in soil under aerobic conditions was $\mathrm{NO}_{3}{ }^{-}-\mathrm{N}$ in our research.

Our result demonstrated that $\mathrm{NH}_{4}{ }^{+}-\mathrm{N}$ was the dominant form of $\mathrm{N}$ in anaerobic conditions which was consistent with the findings of Vimlesh and Giri [53] and Anggria et al. [32], who studied the release of $\mathrm{N}$ from sewage in soils under flooded conditions. In aerobic situations, the total $\mathrm{N}$ release progressively increased with the time of incubation and reached the peak within 75-90 days while in anaerobic situations the release of total $\mathrm{N}$ from manures was higher within 30 days (Figure 2e,f). Our findings are consistent with those of Ling-ling and Shu-tian [54] who studied the changes of organic $\mathrm{N}$ fractions of nine different manures. They discovered that fast $\mathrm{N}$ mineralization from manures in aerobic incubation occurred within 56-84 days which supports our results of fast mineralization within 30-90 days. They also reported that kinds and sources of manures significantly $(p<0.01$ or $p<0.001)$ influenced mineralized $\mathrm{N}$ within 7 to 84 days of the incubation period. Our study revealed that in aerobic conditions, PM produced the maximum available $N$ which was also suggested by Okonkwo et al. [40].

Soil microorganisms transfer $C$ between environmental compartments and utilize different organic and inorganic forms of $\mathrm{C}$ as carbon and energy sources. For microbial metabolism, $\mathrm{C}$ is closely related with other essential elements as electron donors and acceptors in energy transduction or through immobilization and mineralization as part of multiple essential element-containing biomolecules [55]. Therefore, the availability of other key elements essential for life, particularly $\mathrm{N}$ regulates the rate at which microbes consume and respire carbon [56]. As microbes break down the organic matter, a surplus of $\mathrm{N}$ is liberated as $\mathrm{NH}_{4}{ }^{+}$. In aerobic soil, $\mathrm{NH}_{4}{ }^{+}$rapidly converts to nitrate through the process of nitrification. This means that as the $\mathrm{C} / \mathrm{N}$ ratio decreases with advanced manure decomposition, the $\mathrm{N}$ accumulation tends to increase in soil (Figure $2 \mathrm{~g}$ ). When the manure $\mathrm{C} / \mathrm{N}$ ratio is high, the microbial population (particularly heterotrophs) increases and immobilizes $\mathrm{C}$ and $\mathrm{N}$ in their body. As time passes, the $\mathrm{C} / \mathrm{N}$ ratio decreases, and many microbes die. Thus, in the initial days, there would be much competition between microbes and plants for $\mathrm{N}$ and at later days this competition would be less and $\mathrm{N}$ becomes more available to plants. The $\mathrm{C} / \mathrm{N}$ ratio is commonly used to determine whether mineralization or immobilization has occurred. When the $\mathrm{C} / \mathrm{N}$ ratio is less than 20:1, mineralization is likely to occur, but immobilization is more likely when the $\mathrm{C} / \mathrm{N}$ ratio is more than 30:1. The content of manure, as well as local management techniques such as treatment, storage, and field application, as well as ambient meteorological circumstances, have a significant impact on nutrient mineralization. To maintain soil fertility the most suitable source of the organic amendment should be chosen according to the needs of the farm. The timely and correct amount of manure application will reduce deficiency or excessive use of nutrients for crop production, ensure balanced fertilization and finally contribute to saving our environment through emitting fewer greenhouse gases. 


\section{Conclusions}

Nutrient availability is affected by the incorporation of organic manures that differ in quality and there should be proper addition of manures in the soil to optimize their nutrient release and synchronize with the crop demand. Based on this incubation experiment, we found that the first-order kinetic cumulative model could fit well with the observed $C$ and $\mathrm{N}$ mineralization data of all cases. The present study also suggests that $\mathrm{C}$ and $\mathrm{N}$ mineralization in soil was greater in aerobic than anaerobic conditions. MR had the highest release of $\mathrm{NH}_{4}{ }^{+}-\mathrm{N}$ and $\mathrm{NO}_{3}{ }^{-}-\mathrm{N}$ under anaerobic conditions and was more responsive to $\mathrm{C}$ mineralization in both moisture scenarios. Conversely, the soils treated with PM and TC released $\mathrm{NO}_{3}-\mathrm{N}$ and $\mathrm{NH}_{4}{ }^{+}-\mathrm{N}$ markedly higher under the aerobic context. The rapidity of $\mathrm{C}$ and $\mathrm{N}$ mineralization was higher in TC. Thus, the release of nutrient elements from manures after decomposition was significantly influenced by manure types, soil moisture conditions (aerobic and anaerobic), and incubation period. Therefore, depending on mineralization potential, organic matter of varying sources can be used to regulate the timing of nutrient availability and to estimate the best time for planting crops and fertilizer application. Waste management during compost preparation to prevent environmental pollution might be a great challenge for farmers. For this reason, compost should be assessed for its maturity before application in the soil to prevent environmental hazards and slowly mineralizing materials could be useful for crops, as they serve as a long-term source of nutrients. Further research should be carried out concerning the potentials of the manures and composts so that their ability to mineralize slowly can be evaluated. In this way, their advantages to crops will be better understood.

Author Contributions: Conceptualization, M.R.I., M.J. and M.M.R. (Mohammad Mazibur Rahman); methodology, M.R.I., S.B. and M.J.; software, S.B., S.U. and T.S.H.; validation, M.R.I., S.B., M.M.R. (Mohammad Mazibur Rahman) and M.J.; formal analysis, S.B., S.U. and T.S.H.; investigation, M.R.I., S.B., M.M.R. (Mohammad Mazibur Rahman) and M.J.; resources, M.R.I., M.M.R. (Mohammad Mazibur Rahman) and M.J.; data curation, M.R.I., S.B. and T.S.H.; writing—original draft preparation, M.R.I., S.B., T.S.H. and M.M.R. (Mohammad Mazibur Rahman); writing—review and editing, M.R.I., S.B., T.S.H., S.U., M.M.R. (Mohammad Mazibur Rahman), M.J., M.M.R. (Mohammad Mahmudur Rahman), M.A., A.G. and M.A.H.; visualization, M.R.I., T.S.H., M.M.R. (Mohammad Mahmudur Rahman) and M.A.H.; supervision, M.R.I., M.J. and M.M.R. (Mohammad Mazibur Rahman); project administration, M.R.I., M.J. and M.M.R. (Mohammad Mazibur Rahman); funding acquisition, M.R.I., M.J., M.M.R. (Mohammad Mazibur Rahman), M.A. and A.G. All authors have read and agreed to the published version of the manuscript.

Funding: This research was partly funded by the World Bank through its Higher Education Quality Enhancement Project (HEQEP-AIF-UGC/CP009). Also, the research was funded by Taif University Researchers Supporting Project number (TURSP-2020/257), Taif University, Taif, Saudi Arabia.

Institutional Review Board Statement: Not applicable.

Informed Consent Statement: Not applicable.

Data Availability Statement: The data that support this study will be shared upon reasonable request to the corresponding author.

Acknowledgments: We gratefully acknowledge the financial support of the World Bank to carry out this research work. In addition, Majid Alhomrani would like to acknowledge TURSP (2020/257), Taif University, Taif, Saudi Arabia.

Conflicts of Interest: The authors declare no conflict of interest.

\section{References}

1. Rijpma, J.; Jahiruddin, M. National strategy and plan for use of soil nutrient balance in Bangladesh. Consult. Rep. SFFP Khamarbari Dhaka 2004, 43, 7-26.

2. Islam, M. Soil fertility history, present status and future scenario in Bangladesh. Bangladesh J. Agric. Environ. $2008,4,129-151$.

3. Rahman, S.; Islam, M.; Rahman, M.; Oh, D.H. Effect of cattle slurry on growth, biomass yield and chemical composition of maize fodder. Asian Austral. J. Anim. Sci. 2008, 21, 1592-1598. [CrossRef] 
4. Wani, S.; Rupela, O.; Lee, K. Sustainable agriculture in the semi-arid tropics through biological nitrogen fixation in grain legumes. In Management of Biological Nitrogen Fixation for the Development of More Productive and Sustainable Agricultural Systes; Springer: Berlin/Heidelberg, Germany, 1995; pp. 29-49.

5. Escobar, M.O.; Hue, N. Temporal changes of selected chemical properties in three manure-Amended soils of Hawaii. Bioresour Technol. 2008, 99, 8649-8654. [CrossRef] [PubMed]

6. Rahman, M.H.; Islam, M.R.; Jahiruddin, M.; Puteh, A.B.; Mondal, M.M.A. Influence of organic matter on nitrogen mineralization pattern in soils under different moisture regimes. Int. J. Agric. Biol. 2013, 15, 55-61.

7. Cai, A.; Xu, H.; Shao, X.; Zhu, P.; Zhang, W.; Xu, M.; Murphy, D.V. Carbon and nitrogen mineralization in relation to soil particle-size fractions after 32 years of chemical and manure application in a continuous maize cropping system. PLoS ONE 2016, 11, e0152521. [CrossRef]

8. Hossain, M.B.; Rahman, M.M.; Biswas, J.C.; Miah, M.M.U.; Akhter, S.; Maniruzzaman, M.; Choudhury, A.K.; Ahmed, F.; Shiragi, M.H.K.; Kalra, N. Carbon mineralization and carbon dioxide emission from organic matter added soil under different temperature regime. Int. J. Recycl. Org. Waste Agric. 2017, 6, 311-319. [CrossRef]

9. van Gestel, M.; Ladd, J.N.; Amato, M. Carbon and nitrogen mineralization from two soils of contrasting texture and microaggregate stability: Influence of sequential fumigation, drying and storage. Soil Biol. Biochem. 1991, 23, 313-322. [CrossRef]

10. Datta, A.; Jat, H.S.; Yadav, A.K.; Choudhary, M.; Sharma, P.C.; Rai, M.; Singh, L.K.; Majumder, S.P.; Choudhary, V.; Jat, M.L. Carbon mineralization in soil as influenced by crop residue type and placement in an Alfisols of Northwest India. Carbon Manag. 2019, 10, 1-14. [CrossRef]

11. Pramanik, P.; Safique, S.; Zahan, A.; Phukan, M.; Ghosh, S. Cellulolytic microorganisms control the availability of nitrogen in microcosm of shredded pruning litter treated highly acidic tea-growing soils of Assam in Northeast India. Appl. Soil Ecol. 2017, 120, 30-34. [CrossRef]

12. Waldrop, M.P.; Holloway, M.J.; Smith, D.B.; Goldhaber, M.B.; Drenovsky, R.E.; Scow, K.M.; Dick, R.; Howard, D.; Wylie, B.; Grace, J.B. The interacting roles of climate, soils, and plant production on soil microbial communities at a continental scale. Ecology 2017, 98, 1957-1967. [CrossRef] [PubMed]

13. Dessureault-Rompré, J.; Zebarth, B.J.; Georgallas, A.; Burton, D.L.; Grant, C.A.; Drury, C.F. Temperature dependence of soil nitrogen mineralization rate: Comparison of mathematical models, reference temperatures and origin of the soils. Geoderma 2010, 157, 97-108. [CrossRef]

14. Guntiñas, M.E.; Leirós, M.C.; Trasar-Cepeda, C.; Gil-Sotres, F. Effects of moisture and temperature on net soil nitrogen mineralization: A laboratory study. Eur. J. Soil Biol. 2012, 48, 73-80. [CrossRef]

15. Ros, G.H.; Hanegraaf, M.C.; Hoffland, E.; van Riemsdijk, W.H. Predicting soil N mineralization: Relevance of organic matter fractions and soil properties. Soil Biol. Biochem. 2011, 43, 1714-1722. [CrossRef]

16. Dessureault-Rompré, J.; Zebarth, B.J.; Burton, D.L.; Georgallas, A. Predicting soil nitrogen supply from soil properties. Can. J. Soil Sci. 2015, 95, 63-75. [CrossRef]

17. Senwoand, Z.N.; Tabatabai, M.A. Effect of management systems on nitrogen mineralization and nitrification in soils. Commun. Soil Sci. Plant Anal. 2005, 36, 1313-1326.

18. Wade, J.; Horwath, W.R.; Burger, M.B. Integrating soil biological and chemical indices to predict net nitrogen mineralization across California agricultural systems. Soil Sci. Soc. Am. J. 2016, 80, 1675-1687. [CrossRef]

19. Weeraratna, C.S. Pattern of nitrogen release during decomposition of some green manures in a tropical alluvial soil. Plant Soil 1979, 53, 287-294. [CrossRef]

20. Nelson, D.W.; Sommer, L.E. Total Carbon, Organic Carbon and Organic Matter. In Methods of Soil Analysis, Part 2; Page, A.L., Miller, R.H., Keeney, D.R., Eds.; ASA and SSSA: Madison, WI, USA, 1982; pp. 539-579.

21. Walkey, J.A.; Black, J. Estimation of organic carbon by the chromic acid titration method. Soil Sci. 1934, 37, 29-31.

22. Piper, C.S. Soil and Plant Analysis: A Laboratory Manual of Methods for the Examination of Soils and the Determination of the Inorganic Constituents of Plants; Inter science publishers Inc.: New York, NY, USA, 1946.

23. Yamakawa, T. Laboratory methods for soil science and plant nutrition. In Methods of Plant Analysis, Part 2, JICA-IPSA Project; American Society of Agronomy, Inc.: Madison, WI, USA, 1992; pp. 6-14.

24. Black, C.; Evans, D.; White, J.; Ensminger, L.; Clark, F. Methods of Soil Analysis, Part (1) and Part (2); American Society of Agronomy Inc.: Madison, WI, USA, 1965.

25. STPM (Malaysian Higher School Certificate). Soil Testing Procedure Manual; Marathwada Agricultural University: Parbhani, India, 2008; p. 22.

26. Chapman, H. Cation exchange capacity. In Methods of Soil Analysis: Part 2; Black, C.A., Ed.; American Society of Agronomy, Inc.: Madison, WI, USA, 1965; Volume 9, pp. 891-901.

27. Jackson, M.; Miller, R.; Forkiln, R. Soil Chemical Analysis; Prentic-Hall of India Pvt. \& Ltd.: New Delhi, India, $1973 ;$ p. 498.

28. Bremner, J.M.; Mulvaney, C.S. Total nitrogen. In Methods of Soil Analysis Part 2, 2nd ed.; Page, A.L., Ed.; American Society of Agronomy: Madison, WI, USA, 1982; p. 595.

29. Olsen, S.R.; Cole, C.V.; Watanabe, F.S.; Dean, L.A. Estimation of Available Phosphorus in Soils by Extraction with Sodium Bicarbonate; US Department of Agriculture, Circular 19: Washington, DC, USA, 1954; p. 939.

30. Knudsen, D.; Peterson, G.; Pratt, P. Lithium, sodium, and potassium. Methods of Soil Analysis: Part 2. Chem. Microbiol. Prop. 1983, 9, 225-246. 
31. Williams, C.; Steinbergs, A. Soil sulphur fractions as chemical indices of available sulphur in some Australian soils. Austral. J. Agric. Res. 1959, 10, 340-352. [CrossRef]

32. Anggria, L.; Kasno, A.; Rochayati, S. Effect of organic matter on nitrogen mineralization in flooded and dry soil. J. Agric. Biol. Sci. 2012, 7, 586-590.

33. Kader, M.; Sleutel, S.; Begum, S.A.; Moslehuddin, A.Z.M.; De Neve, S. Nitrogen mineralization in sub-tropical paddy soils in relation to soil mineralogy, management, $\mathrm{pH}$, carbon, nitrogen and iron contents. Eur. J. Soil Sci. 2013, 64, 47-57. [CrossRef]

34. Goldman, E.; Jacobs, R. Determination of nitrates by ultraviolet absorption. J. Am. Water Works Assoc. 1961, 53, 187-191. [CrossRef]

35. Kempers, A. Determination of sub-microquantities of ammonium and nitrates in soils with phenol, sodium nitroprusside and hypochlorite. Geoderma 1974, 12, 201-206. [CrossRef]

36. Page, A.; Miller, R.; Keeney, D. Methods of Soil Analysis. Part 2; American Society of Agronomy; Soil Science Society of America: Madison, WI, USA, 1982; pp. 403-430.

37. Wilde, S.; Voigt, G.; Lyer, J. Soil and Plant Analysis for Tree Culture; Oxford and IBH: New Delhi, India, $1972 ;$ p. 172.

38. Stanford, G.; Smith, S. Nitrogen mineralization potentials of soils. Soil Sci. Soc. Am. J. 1972, 36, 465-472. [CrossRef]

39. Murthy, R.K.; Basavaraj, B.; Raveendra, H. Carbon mineralization in soil amended with weeds and their composts. Karnataka J. Agric. Sci. 2010, 23, 514-516.

40. Okonkwo, C.; Nwite, J.; Onyibe, C.; Nweke, I.; Mbah, C. Animal manures mineralization and plant nitrogen uptake in an ultisol in Abakaliki Southeast Nigeria. J. Agric. Biol. Sci. 2011, 2, 123-128.

41. Makinde, E.; Ayeni, L. Determination of mineralization rate of organic materials using carbon dioxide evolution as an index. Int. J. Plant Soil Sci. 2013, 2, 16-23. [CrossRef] [PubMed]

42. Rahman, M. Carbon sequestration options in soils under different crops and their management practices. Agriculturists 2010, 8, 90-101.

43. Devêvre, O.C.; Horwáth, W.R. Decomposition of rice straw and microbial carbon use efficiency under different soil temperatures and moistures. Soil Biol. Biochem. 2000, 32, 1773-1785. [CrossRef]

44. Ilstedt, U.; Nordgren, A.; Malmer, A. Optimum soil water for soil respiration before and after amendment with glucose in humid tropical acrisols and a boreal mor layer. Soil Biol. Biochem. 2000, 32, 1591-1599. [CrossRef]

45. Ruser, R.; Flessa, H.; Russow, R.; Schmidt, G.; Buegger, F.; Munch, J. Emission of $\mathrm{N}_{2} \mathrm{O}, \mathrm{N}_{2}$ and $\mathrm{CO}_{2}$ from soil fertilized with nitrate: Effect of compaction, soil moisture and rewetting. Soil Biol. Biochem. 2006, 38, 263-274. [CrossRef]

46. Beare, M.; Gregorich, E.; St-Georges, P. Compaction effects on $\mathrm{CO}_{2}$ and $\mathrm{N}_{2} \mathrm{O}$ production during drying and rewetting of soil. Soil Biol. Biochem. 2009, 41, 611-621. [CrossRef]

47. Saidy, A.R. Relationship between water content and mineralization of carbon and nitrogen in soils varying in physical and chemical characteristics. J. Tropic. Soils 2013, 18, 45-52. [CrossRef]

48. Taggart, M.; Heitman, J.; Shi, W.; Vepraskas, M. Temperature and water content effects on carbon mineralization for sapric soil material. Wetlands 2012, 32, 939-944. [CrossRef]

49. Skopp, J.; Jawson, M.; Doran, J. Steady-state aerobic microbial activity as a function of soil water content. Soil Sci. Soc. Am. J. 1990, 54, 1619-1625. [CrossRef]

50. Wen, X.F.; Yu, G.R.; Sun, X.M.; Li, Q.K.; Liu, Y.F.; Zhang, L.M.; Ren, C.Y.; Fu, Y.L.; Li, Z.Q. Soil moisture effect on the temperature dependence of ecosystem respiration in a subtropical Pinus plantation of southeastern China. Agric. Forest Meteorol. 2006, 137, 166-175. [CrossRef]

51. Naher, U.; Hashem, M.; Uddin, M.; Ahmed, M.; Saleque, M. Carbon mineralization and carbon dioxide evolution rate of cowdung and poultry manure along with rice straw and lime under covered condition in the tropical environment. Pakistan. J. Biol. Sci. 2004, 7, 155-158. [CrossRef]

52. Walpola, B.; Arunakumara, K. Effect of salt stress on decomposition of organic matter and nitrogen mineralization in animal manure amended soils. J. Agric. Sci. Sri. Lanka 2010, 5, 9-18. [CrossRef]

53. Vimlesh, K.; Giri, A. Nitrogen mineralization in soil amended with crop residue: An incubation experiment under flooding conditions. E. J. Chem. 2011, 8, 25-28. [CrossRef]

54. Ling-ling, L.I.; Shu-tian, L.I. Nitrogen mineralization from animal manures and its relation to organic N fractions. J. Integr. Agric. 2014, 13, 2040-2048.

55. Gougoulias, C.; Clark, J.M.; Shaw, L.J. The role of soil microbes in the global carbon cycle: Tracking the below- ground microbial processing of plant-derived carbon for manipulating carbon dynamics in agricultural systems. J. Sci. Food Agric. 2014, 94, 2362-2371. [CrossRef] [PubMed]

56. Davidson, E.A.; Janssens, I.A. Temperature sensitivity of soil carbon decomposition and feedbacks to climate change. Nature 2006, 440, 165-173. [CrossRef] [PubMed] 